\title{
The Development and Evaluation of Employability within the Fashion Curriculum: A Case Study
}

\author{
Lesley Peacock and Elaine McNeill \\ Liverpool John Moores University, Liverpool School of Art and Design
}

\section{Introduction}

This case study describes the development of a pedagogical model to embed employability into a 24-credit Professional Practice module at Level 6 for a Fashion BA Hons programme at Liverpool John Moores University (LJMU). This model was developed by redesigning the focus, structure and delivery and is informed by current HE employability research. In line with the Wilson Review (Wilson, 2012), the programme has worked towards strengthening and facilitating links with local industry for live projects, events and placements. Within the past decade, there has been a plethora of reports and research to implement models of embedded employability, but to date there is no reported evidence of robust evaluation of methods of delivery and evaluation of impact of work-based learning within the Fashion curriculum.

The rationale behind the development of this module was directly linked to the expectation of knowledge and skills in the fashion sector. The academic and vocational skills a Fashion graduate has to offer no longer satisfy industry requirements; instead, fashion employers identify, as recruitment essentials: work experience, transferable skills and degree classification. Increased Higher Education fees have focused attention on employability: the most frequently asked questions from potential students and parents at LJMU Fashion Open Days now relate to graduate progression. In The Guardian, Professor Helen Higson (ProVice-Chancellor, Aston University) welcomed the Wilson review. She discussed the need to focus on employability and the need to forge links and partnerships with business:

'Placements don't just provide employment experience, they also help students develop their self-confidence and ensure graduates are used to the disciplines of the jobs market - such as punctuality, organisational skills and meeting deadlines.' (Higson, 2012)

\section{Background}

The Professional Practice module was introduced to a newly-validated programme in 2011, with the intention of preparing students for graduate employment through the embedding of work placements, live projects and competitions into a year-long, 24-credit module. This module, designed to run alongside three others, is stand-alone, but does cross over into elements of activities undertaken on the design-based modules.

The module is mandatory for all Level 6 students on both the communication and design pathways. Examination of the low uptake of work experience by previous cohorts pointed to several key factors:

- The financial implications of working away from university (unpaid short placements, often London-based).

- The effort involved in finding work placements.

- Course work overload. 
- Lack of understanding of the importance to learning of engagement with the range of interlinked tasks and activities.

- Non-relation of PDP (personal development planning) to progression.

The lack of student engagement in this Professional Practice module was evidenced by the students' end-of-year grades and progression into employment and postgraduate education. During the first three years, all students passed the learning outcomes and assessment criteria, but elements of the work lacked focus and direction. There was a clear need for an elevated standard of attainment in areas of self-awareness (Watts, 2006) and evaluative reflection about both themselves and others (Knight and Yorke, 2003).

The structure and delivery of the module was flawed and did not succeed in engaging the students in the activities provided. It was important to re-evaluate the module in the context of the whole programme, with special regard to embedding and linking employability-related modules from Levels 4 to 6 , to enable students to develop personal autonomy (Yorke and Knight, 2006). It was also key to ensure that LJMU's employability strategy was embedded into the Fashion curriculum.

In 2007, LJMU developed a World of Work Programme for all students, in response to Government reports and the need to develop graduate skills in Higher Education. The initiative was developed in consultation with local and national employers; it aimed to ensure that every student recognised the skills needed to stand out from applicants from competitor institutions and engage successfully in the world of work. The programme required students to analyse their skills and competencies and develop personal statements simulating the application process.

To counter low attendance at the World of Work sessions, it was important that the students could make a direct link between engagement and employability.

\section{Problem - What we needed to do}

Fashion academics faced a complex range of issues and needed to adopt a holistic approach to engage large numbers (68 in the 2012/13 cohort) with a variety of employers and curricular assessment, as well as to embed institutional PDP and employability strategies. Employer engagement would require the programme to be flexible and commercially responsive, whilst remaining academically robust. Like other areas of transformation within Higher Education, the development of Work-Based Learning programmes which involved collaboration between universities, employers and other stakeholders could be complicated and time-consuming.

In the context of graduates, the term 'employability' can be defined in a number of ways. There is a broad consensus that qualities, characteristics, skills and knowledge increase the chances of graduate employment. Graduates are expected to have technical and discipline competences from their degrees, but should also demonstrate a range of broader skills and attributes that include analysing, problem-solving, team-working, communication, interpersonal skills, planning and organising. A report on the Employers' Perceptions of the Employability Skills of New Graduates highlights research undertaken by Harvey et al (1997): 'most employers are looking for graduates who are proactive, can use higher level skills including analysis, critique, synthesis and multi-layered communication to facilitate 
innovative teamwork in catalysing the transformation of their organization' (Harvey, cited by Lowden et al, 2011). Our task was to create opportunities for students to demonstrate the skills that employers wanted, but still work within an educational framework. The participation in work placements, live projects and competitions would need to promote 'skills, understandings and personal attributes' (Knight and Yorke, 2006) to enable Fashion graduates to benefit themselves and the wider community.

Taking a longer-term view, a later case study by Harvey and Locke (2002) suggests that employability is not just about gaining a graduate job; it implies something about the capacity of the graduate to function in a job and be able to move between jobs, thus remaining employable throughout his or her life. An employability model produced by the Sector Skills Council highlights that individual need will be based on the point at which someone is in his/her career (Belt et al, 2010). This recognises the importance of continued professional development to sustain a career. Often the creative graduate will work freelance and have a number of jobs and a portfolio of clients. This typical creative portfolio career is documented in the Creative Graduate Creative Futures longitudinal report, which states: 'Portfolio careers are well established, with 48 per cent of graduates in multiple jobs at the time of the survey, typically combining employment with self-employment, study or developing their creative practice' (Ball et al 2010). It is therefore important that a Fashion professional practice module reflects this career dynamic.

\section{Employer Engagement}

One of the challenges of the Professional Practice module was to engage students in a realworld environment that fostered creative practice and encouraged professional development. We recognised that it was essential for graduates to put their creative practice at the centre of their future progression (Ball, ibid). Gaining entry to the fashion industry requires Fashion graduates to be resourceful and to demonstrate a willingness to work hard; there is also the challenge of collaborating with several partners from a variety of industry contexts. The module required a coherent structure and the flexibility to engage with a number of industry employers.

It was important that individual students were able to identify work experience opportunities that would be pertinent to their own career development. Unpaid internships are a given in the fashion industry and this is a defining factor for students when deciding to apply for work experience. LJMU fashion students are encouraged to engage in placements from their first year of study; this allows a variety of industry experiences to support their professional development.

\section{Curricular Assessment}

The assessment criteria changed to include a broad range of activities under the component weightings of the module to include PDP, competitions, live projects and a diffusion project, as well as a work placement report or a market report. This diversity was designed to provide alternatives to work placements, whilst also ensuring that the students undertook a range of activities which would support their own interests and professional development. 


\section{Embedding PDP and Institutional Employability}

The design of the curriculum had to be revisited to ensure that all three years of the programme were interlinked from Level 4 to Level 6 , in order to create a streamlined delivery for PDP and career-focused modules. This incorporated the School's PDP questionnaires, designed to unify personal tutorials throughout the School and embed the institutional World of Work programme stages: Bronze (Level 4), Silver (Level 5) and Gold (Level 6). The World of Work team was scheduled to deliver workshops in the module, with Fashion staff in attendance, which highlighted to students the value of engagement.

The delivery of the module was a year long, with formative feedback and one-to-one feedback points throughout semesters 1 and 2. This feedback was structured to enable individual students to reflect on their experience and identify how they could build their individual career pathway, to encourage ownership and autonomy in their learning (Bryan and Clegg, 2006). An integrated learning environment was necessary to encourage studentcentred learning. We intended to support the students' individual personal and professional development by facilitating experiential learning, dialogue and reflection (Race and Pickford, 2007). We scheduled a range of learning activities to draw on the existing talents and abilities of the students, to build their confidence through industry participation and place their aptitudes in an industry context. The activities incorporated a variety of teaching and learning methods and, where possible, we aimed to locate the students' learning in authentic contexts to replicate real-world scenarios (Table 1).

Table 1

\begin{tabular}{|l|l|l|}
\hline $\begin{array}{l}\text { Professional } \\
\text { Practice Learning } \\
\text { Activity }\end{array}$ & Definition & Desired Learning Outcome \\
\hline Employer Engagement & \multicolumn{2}{|l|}{} \\
\hline Live Projects & $\begin{array}{l}\text { Live projects are activities set for } \\
\text { students by commercial clients or } \\
\text { community partners. Briefs for projects } \\
\text { are developed in consultation between } \\
\text { academics and external partners to } \\
\text { solve a particular industry-relevant } \\
\text { problem. Such projects may involve } \\
\text { visits to workplaces or introductions by } \\
\text { employers. }\end{array}$ & $\begin{array}{l}\text { Students locate their learning in } \\
\text { authentic contexts and hone } \\
\text { their decision-making, } \\
\text { communication and team- } \\
\text { working skills whilst } \\
\text { acknowledging industry } \\
\text { perspectives. }\end{array}$ \\
\hline Placements & $\begin{array}{l}\text { Work placement is a term loosely } \\
\text { applied to any formal, structured work } \\
\text { experience. Organisations may have a } \\
\text { structured scheme which could include } \\
\text { working on a specific project and/or } \\
\text { shadowing, by which students gain a } \\
\text { working knowledge of various } \\
\text { departments. }\end{array}$ & $\begin{array}{l}\text { Students will be able to assess } \\
\text { and develop relevant } \\
\text { transferable graduate skills. } \\
\text { They will also be provided with } \\
\text { an opportunity to explore their } \\
\text { chosen career paths. }\end{array}$ \\
\hline $\begin{array}{l}\text { These real-world scenarios give the } \\
\text { students insight into the pressures and } \\
\text { issues that have to be managed by }\end{array}$ & $\begin{array}{l}\text { Students practise the type of } \\
\text { negotiation and creativity } \\
\text { required of them as }\end{array}$ \\
\hline Industry Competitions
\end{tabular}




\begin{tabular}{|c|c|c|}
\hline & $\begin{array}{l}\text { industry professionals in day-to-day } \\
\text { operations. }\end{array}$ & professionals. \\
\hline Guest Lectures & $\begin{array}{l}\text { Guest lectures set the scene for } \\
\text { students to learn about industry } \\
\text { opportunities and characteristics. }\end{array}$ & $\begin{array}{l}\text { Students learn about specific } \\
\text { industry roles and develop } \\
\text { valuable contacts. }\end{array}$ \\
\hline Career Fairs & $\begin{array}{l}\text { Recruitment events give students the } \\
\text { opportunity to meet potential employers } \\
\text { face to face. Students are encouraged } \\
\text { to attend a range of events at LJMU, } \\
\text { regionally and nationally, including } \\
\text { Graduate Fashion Week. }\end{array}$ & $\begin{array}{l}\text { Students meet with industry } \\
\text { contacts, especially HR } \\
\text { personnel, to ensure that they } \\
\text { are aware of employment } \\
\text { opportunities. Students can } \\
\text { network. }\end{array}$ \\
\hline \multicolumn{3}{|c|}{ Institutional Employability Strategy } \\
\hline $\begin{array}{l}\text { Career Development } \\
\text { Workshops }\end{array}$ & $\begin{array}{l}\text { These workshops are led by the LJMU } \\
\text { careers team and include: CV writing, } \\
\text { mock interviews and presentations. }\end{array}$ & $\begin{array}{l}\text { Students develop and learn } \\
\text { skills pertinent to the recruitment } \\
\text { process. }\end{array}$ \\
\hline $\begin{array}{l}\text { LJMU World of Work } \\
\text { Initiative }\end{array}$ & $\begin{array}{l}\text { LJMU's World of Work Programme aims } \\
\text { to ensure that all students are equipped } \\
\text { with the skills they need to stand out } \\
\text { from applicants from competitor } \\
\text { institutions and successfully engage in } \\
\text { the world of work. }\end{array}$ & $\begin{array}{l}\text { Students write personal } \\
\text { statements to demonstrate that } \\
\text { they meet the World of Work } \\
\text { skills criteria: Self-Awareness, } \\
\text { Organisational Awareness and } \\
\text { Making Things Happen. }\end{array}$ \\
\hline \multicolumn{3}{|l|}{ Tutorials } \\
\hline $\begin{array}{l}\text { One-to-one PDP } \\
\text { Tutorials }\end{array}$ & $\begin{array}{l}\text { Intensive personal and professional } \\
\text { development tutorials for individual } \\
\text { students. }\end{array}$ & $\begin{array}{l}\text { Students become more aware of } \\
\text { their own abilities, aptitudes and } \\
\text { aspirations and are offered } \\
\text { development advice. }\end{array}$ \\
\hline $\begin{array}{l}\text { Seminar Group } \\
\text { Tutorials }\end{array}$ & $\begin{array}{l}\text { Focused personal and professional } \\
\text { development tutorials for small groups } \\
\text { of students. }\end{array}$ & $\begin{array}{l}\text { Students engage in } \\
\text { collaborative and interactive } \\
\text { learning with their peers. }\end{array}$ \\
\hline \multicolumn{3}{|l|}{ Assessment } \\
\hline Portfolios & $\begin{array}{l}\text { A systematic body of student work } \\
\text { relating to the students' professional } \\
\text { practice activities and accomplishments. }\end{array}$ & $\begin{array}{l}\text { Students reflect and evaluate as } \\
\text { they assemble work that } \\
\text { illustrates their talents and } \\
\text { achievements. }\end{array}$ \\
\hline
\end{tabular}

\section{Outcomes of employer engagement}

During the year, the staff team was able to bring in three substantial live projects, which enabled the students to undertake work experience in house. A live project with English National Ballet engaged fourteen students, split into two groups in which project management and creative design roles were allocated. The staff overseeing the project incorporated teaching and learning processes within assessment tasks required for group work and peer learning (Boud et al, 2001). To achieve objectives and outcomes, the students had to plan, liaise and organise the event within a clear framework. It was important that they were able to determine from the outset the context of the project in relation to their 
own learning and individual investigation into work-based learning (Race \& Pickford, 2007). Within the group, the students were assigned individual tasks which enabled a sense of autonomy. The staff formed smaller specialist focus groups to allow all students to contribute and investigate how their performance was working towards their individual assessments. Understanding the student view of group work (Ruddick, 1979) was essential, so that all members of the group would feel that they had contributed effectively, rather than that only the fluent and confident speakers would perform well. The assessment, which was led by the module criteria, allowed the students to concentrate on a clear set of skills to define the final submission.

The transferable skills required by the students to make the group activity work enabled employability to be developed further. Live projects involved a range of processes and understanding, while the reflective assessment process encouraged students to pay attention, not only to the 'content to be learned, but also to the process(es) through which that learning takes place' (Yorke \& Knight, 2006). Positive engagement with industry led the way for several live projects including: Dr Martens (two-day styling shoot), North West Cancer Charity (merchandising and Ovarian Cancer awareness event), Liverpool Community Health (redesigning the uniform for 7,000 national health workers from doctors to nurses and community health care workers). The LCH project was showcased at the end-ofyear catwalk show (2013), with a presentation to the winning student by the Chief Executive of $\mathrm{LCH}$.

For each of the projects they worked on, all members of the cohort were required to present their work to representatives of the organisation and/or industry. Group and individual presentations fed into mid- and end-of-year summative assessment reviews. It was the intention of the staff to engage the students in evaluating and presenting their work as much as possible to understand the benefits for future employability (Marciniak et al, 2013). The students were supported in this activity via workshops from the Careers and World of Work Centre as well as by staff working on the fashion programme.

Fashion students are mainly responsible for obtaining and securing their own placements. Most students who take up placements early in their studies tend to gain several work placement opportunities. Such placements vary from local high-end retail and design outlets to national and international haute couture design, retail, PR and marketing companies; they can last anything from a one-day shoot to a day a week for a whole year and, in many cases, students are working part-time alongside their programme of study. Students who have part-time jobs in high street retail are encouraged to take advantage of the opportunities available from their employers. For one student, this proved most valuable: during her employment with Zara as a retail assistant, she was offered training to become a Zara merchandiser and secured a graduate merchandising role before completing the course. Another student who had completed several industry work placements also gained a graduate role as a menswear buyer at Matalan before graduating. In comparison to the traditional fashion placement academic models, this flexible approach to professional practice combines traditional placements/internships with in-house live projects and structured PDP, allowing staff to guide and nurture the students, to develop their skills and professionalism and to provide structured feedback as the students' performance is assessed both formally and informally. 


\section{Evaluation}

We set out to explore and examine the impact of work-based learning and employer engagement on graduate employability. As part of the online questionnaire, all students were invited to discuss their participation in professional practice activities during their final year of study. These activities included: CV writing, PDP (one-to-one) tutorials, presentation skills, guest lectures, seminar style (group) tutorials, the LJMU World of Work Process, mock interviews, careers fairs and work-based learning (live project and placements). Knight and Yorke (2006) define employability using four broad and inter-related components: subject/industry knowledge, skilful practice, efficacy beliefs and meta-cognition (including self-awareness and a capacity to reflect on development). Adopting these employability characteristics, we analysed three key variables: meta-cognition in relation to career development, skilful practice (employability skills) and industry knowledge. The students were asked to scale all of the professional practice activities in relation to these three areas of development.

The evaluation also included analysis of a 2,500-word, student-assessed placement/market report and professional practice portfolios; we included group tutorial feedback, PDP tutorials and staff reflections.

- All students engaged with a placement and/or live project. 78\% Fashion students (40 out of 51) recognised that they gained industry experience. . Of the eleven students who didn't acknowledge that they had gained industry experience, seven took part in at least one Live Project and four gained work experience as teaching assistants in schools or summer camps abroad.

- $100 \%$ of Fashion students felt that placements were important for their careers. $(29 \%$ Important; 71\% Very Important). Many described how they developed industryspecific technical skills as well as the vital graduate skills, such as communication, team work, time management and negotiation ability.

- Several students defined their employer engagement experiences as a significant factor in deciding their future career paths. Some students also recognised the benefit of developing fashion industry contacts whilst on work experience.

Figure 1. Student perceptions as to which professional practice activity helped develop their career progression

\section{Career Progression}

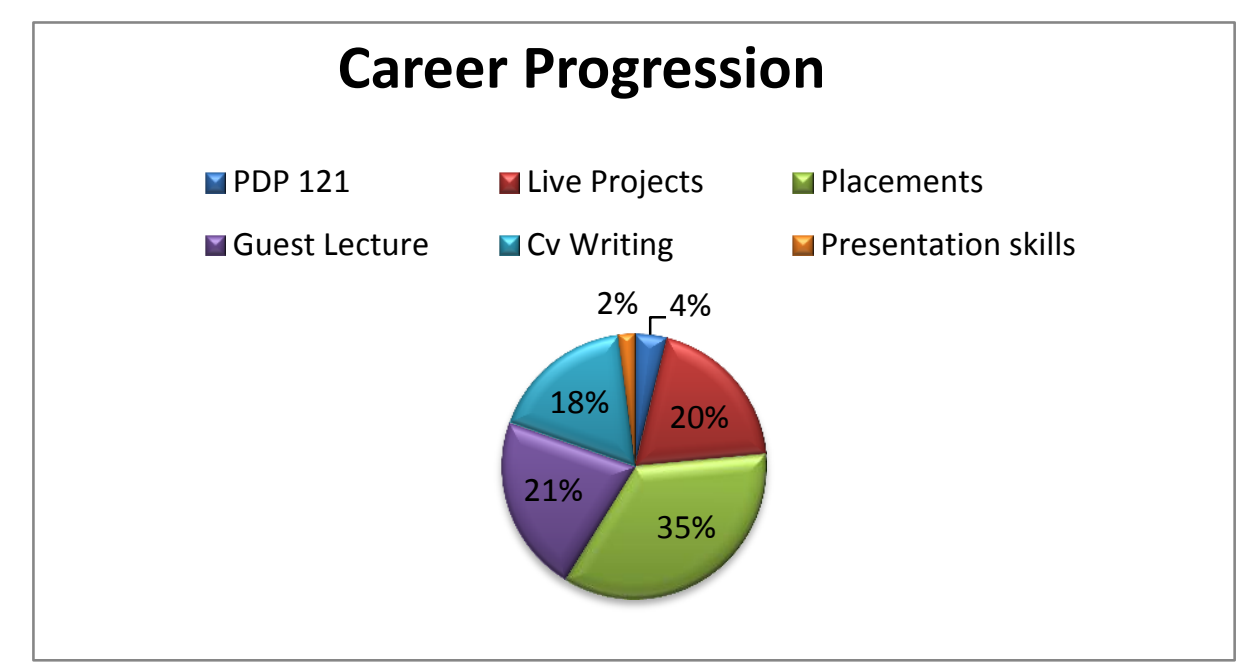


Figure 2. Student perceptions as to which professional practice activity has raised awareness of relevant employability skills

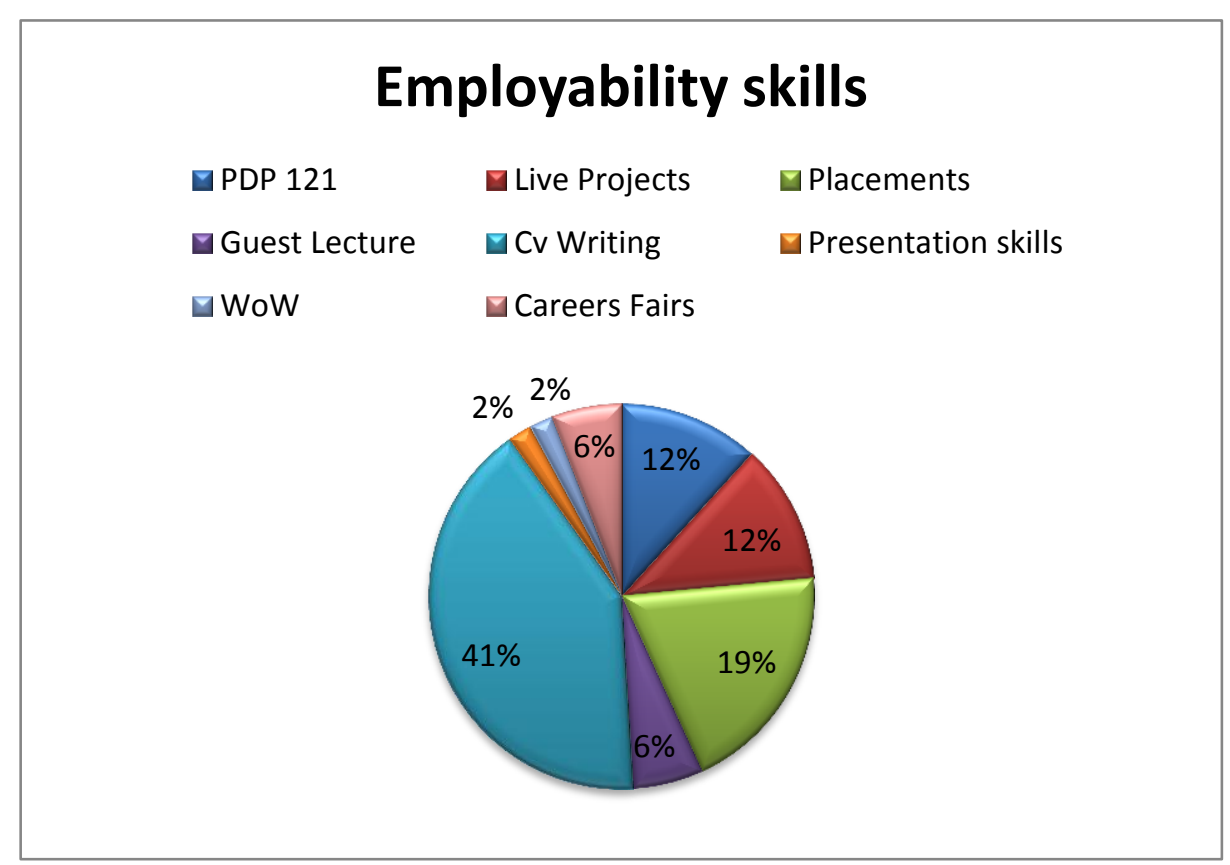

The students were able to reflect on the skills they had used during their work experience and live projects to tailor their CVs and applications for specific roles in the fashion industry. Feedback from the cohort indicated that workshops for cover letters and CV writing had been useful in developing confidence when applying for positions across the sector.

Students were extremely positive about guest lectures and particularly valued talks from alumni. Most students commented on how these talks gave them a real-world insight into the fashion industry. We also noted the impact of the timing of these lectures: students were more career-focused by the second semester of the final year.

Figure 3. Student perceptions as to which professional practice activity increased fashion industry knowledge

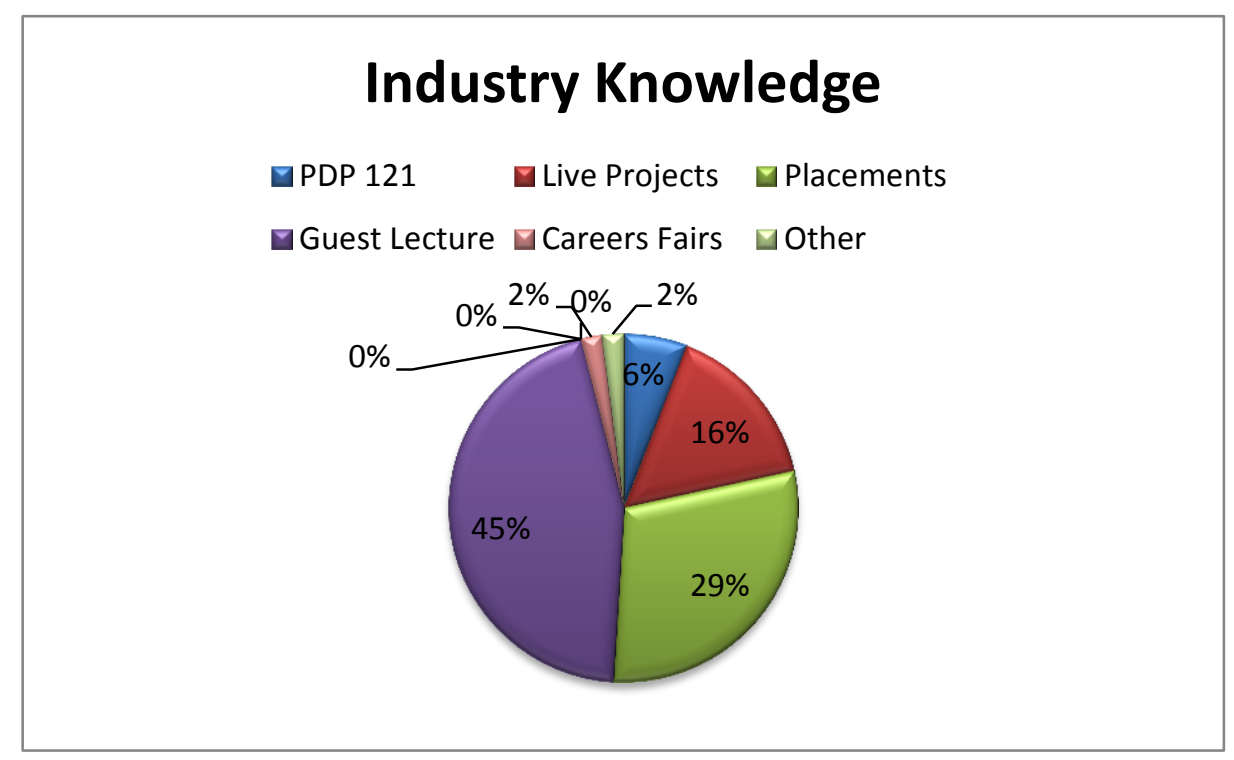




\section{Conclusion}

In conclusion, the cumulative evidence suggests that there has been a shift in the students' perception of employer and industry engagement. The significant transformation of this module has generated a rich professional development and industry context, although we recognise that there are still improvements and challenges ahead. The evaluation highlights a need for live projects, placements, guest lectures and CV support. We shall also be introducing summative feedback at points throughout the academic year, to enable students to experience and recognise progression. It is clear that students who engage with a number of industry-focused activities during their studies are more likely to gain graduate employment within their chosen field than students who do not participate.

The staff team was able to deliver a curriculum that embedded the challenges of the workplace within the context of the aims and outcomes of the module. The work placement report (2,500 words) enabled students to reflect on their experience in the context of their ambitions for future employment. The situations presented to students during live projects added to the students' exposure to the skills fashion employers demand: analysing, problemsolving, team-working, communication, interpersonal skills, planning and organising.

We have followed the cohort which undertook this module and the results so far are very promising, with over $30 \%$ engaging in work experience and/or paid internships on graduation and with a further $30 \%$ in paid work in the fashion sector. In January 2014 , two graduates from this cohort came in with the head of PR from Matalan to talk to the undergraduates. One student entered and won a live Matalan competition run at the end of the Professional Practice module. The student's designs were manufactured and featured in Matalan's newlyopened city centre store in Liverpool. On graduation, the student applied to the company and secured employment as a designer. With support from staff, the other student, whilst studying in her final semester, applied for and gained a post at Matalan.

For many of our graduates, employment in the fashion sector is preferable and desirable, but any work is a first option to pay bills and enable an independent lifestyle. A number of students work in fashion retail during their studies and continue to do so as graduates. This is complemented by freelance work within the creative sector to build a portfolio of experience and skills for future employment in their preferred area.

It has been interesting to note that the students who engaged the most in the Professional Practice module and sessions (silver and gold awards) with the World of Work team have gained paid employment in their chosen fields of study. We are currently in discussions with the World of Work team and Careers Centre at LJMU regarding embedding the Silver and Gold awards into the curriculum in Levels 5 and 6 (Bronze is currently mandatory in all LJMU Level 4 modules).

Overall, these findings encourage programmes to engage with employers as much as possible to support and increase opportunities for future cohorts of students. The results provide a positive benchmark from which to build and expand our graduates' opportunities. 


\section{References}

Ball, L., Pollard, E. and Stanley, N. (2010) Creative Graduates Creative Futures, London: Council for Higher Education in Art and Design and University of the Arts.

Belt, V., Drake, P.,and Chapman, K. (2010) Employability Skills: A Research and Policy Briefing. London: UK Commission for Employment and Skills.

Boud,D.,Cohen,R.,Sampson.,J (2001). Peer Learning in Higher Education, London: Kogan Page.

Bryan,C.and Clegg,K (2006) Innovative Assessment in Higher Education. London: Routledge.

Gee L. \& Pickard,H.(2011) 'Shaping Future Fashion Leaders' in:Kemp P,and atfield R, (eds) (2011) 'Enhancing Graduate Impact in business and management, hospitality, leisure,sport,tourism', Threshold Press.

Harvey, L., Locke, W. and Morey, A. (2002) Enhancing Employability, Recognising Diversity, London: Universities UK.

Higson, H. (2012) 'How to improve employability: Aston University's placements programme, The Guardian, $29^{\text {th }}$ February 2012, http://www.theguardian.com/higher-educationnetwork/blog/2012/feb/29/aston-university-student-placements

Lowden, K., Hall, S., Elliot, D. and Lewin, J. (2011) Employers' perceptions of the employability of new graduates, London: Edge Foundation.

Leitch, S. (2006) The Leitch Review of Skills. Prosperity for all in the global economy - world class skills. Final Report. London: The Stationery Office.

Marciniak, R.; Holley D. \& Dobson C. (2013) "Fashion Students Engaging in Iconic Designs in a Business Work", chapter in P. Mclntosh \& D. Warren "Creativity in the Classroom: Case Studies in Using the Arts in Teaching and Learning in Higher Education, The University ofChicago Press.

McConnell, C. (2008) 'Fashion, Textiles and Related Industries: Work-related Learning and the Student Experience' in Networks Magazine, HEA Art Design Media Subject Centre. Issue 5, Autumn 2008.

McQuaid,R and Lindsay,C .(2006) 'The Concept of Employability' in McQuaid, R., Green, A. and Danson, M. (eds.) Employability and the Local Market, London: Routledge.

Knight, P. and Yorke, M. (2003) Assessment, Learning and Employability, Buckingham: Open University Press.

Race,P and R,Pickford (2007) Making Teaching Work, London: SAGE.

Robertson, A. (2008) 'Learning on Placement: An investigation of work placement opportunities within the designer-maker community' in Networks Magazine, HEA Art Design Media Subject Centre. Issue 5, Autumn 2008.

Robertson,C \& Scott,M.(2010) 'Personal Enquiry Project: Students'Perceptions of World of Work Initiatives; does anybody know that they're out there? Innovations in Practice', Centre for Excellence in Teaching \& Learning (CETL) Issue 6, November 2010 
Ruddick J.(1979) Learning Through Small Group Discussion, Bournemouth: Direct Design Ltd.

Watts, A. G. (2006) 'Career development learning and employability', in Learning and Employability. Series Two, York: The Higher Education Academy.

Whyte, W. (1991) Participatory Action Research. London: Sage

Wilson, T. (2012) A Review of Business-University Collaboration. London: Department for Business Innovation and Skills.

Yorke, M. (2006) 'Employability in higher education: what it is, what it is not', Learning and Employability. Series One. York: The Higher Education Academy.

Yorke, M. and Knight, P. (2006) 'Embedding Employability into the Curriculum', Learning and Employability. Series One. York: The Higher Education Academy. 